\title{
Independence on the Quarterdeck: Three Baltimore Seafarers, Spanish America, and the Lives of Captains in the Early American Republic
}

\section{David Head}

Ce manuscrit utilise des récits biographiques de trois capitaines de Baltimore qui ont navigué en tant que corsaires dans les révolutions hispano-américaines afin de comprendre pourquoi ils l'ont fait et ce que l'expérience de combat pour ces pays étrangers leur signifiait. Avant de rejoindre la cause hispano-américaine, peu les distingue d'autres capitaines et ils n'affichent aucun intérêt dans l'Amérique espagnole. Mais ils ont néanmoins développé un sentiment d'appartenance à l'Amérique espagnole pendant leur service. En retraçant leurs carrières, cet article cherche à explorer la compréhension des capitaines au sujet de la liberté, complétant ainsi d'autres travaux sur sur les notions de marins sur la liberté, et l'ouverture d'une conversation au sujet de la place des capitaines dans l'historiographie maritime.

In December 1815, Captain Joseph Almeida sailed into Cartagena (in present-day Colombia) expecting to find a profitable market in a city fighting for its independence from Spain. Instead, he discovered - too late - that it had fallen to the Spanish, who seized his vessel and threw him in jail. In time, the United States State Department secured his release, and Almeida returned home to Baltimore. But he then faced a decision: what should he do next? ${ }^{1}$

In early 1816, Almeida's fellow Baltimorean Captain James Chaytor faced a similar decision. He had sailed to Buenos Aires, main port of the United Provinces of the Rio de la Plata, also fighting for its independence from Spain, but rather than the eager buyers he expected, Chaytor was greeted by disappointment. "I make a most miserable business," he lamented. Ten thousand miles from home, he also needed to chart a new course. $^{2}$

A year later, Captain John D. Danels came to his own moment of decision after

1 Luis de Onís to James Monroe, 5 September 1815, Monroe to George William Erving, 20 July 1816, Erving to Pedro Cevallos, 26 September 1816, in U.S. Department of State, "Spain-Blockades," 12 Feb. 1818, ASP04 For.rel. 293, United States Serial Set Digital Collection (accessed Nov. 7, 2009), 156-158; Baltimore Price Current, 9 December 1815; Niles Weekly Register (Baltimore), 17 February 1816; Baltimore Patriot, 9 February 1816; Vermont Republican, 22 April 1816.

2 James Chaytor to R.M., Princeton University Rare Books and Special Collections, James Chaytor Papers, 18 April 1816 (hereafter: JCPP).

The Northern Mariner/le marin du nord, XXIII No. 1, (January 2013), 1-20 
wrecking his ship while sailing from Haiti to Baltimore. Danels had been rising both professionally and personally. He owned his own vessel, kept a regular relationship with a prestigious merchant house, and headed a growing family. Now, however, Captain Danels needed a new ship. ${ }^{3}$

All three men chose the same path after their misfortunes: they entered the service of the emerging nations of Spanish America by becoming privateers in the fight for independence from Spain. It was a not uncommon choice for Baltimore captains at the time. In fact, between 1816 and 1820 more than forty privateers sailed from the city. Each man had sailed U.S. privateers or letter of marque traders during the War of 1812, and continuing in a familiar field helped make a living for a time. But something happened to these captains as they sailed for Spanish America. Captain Chaytor began calling himself "Diego," the Spanish version of his name - even in letters to his wife. Captain Almeida swore revenge against the nation that had imprisoned him. And Captain Danels enjoyed a wild ride that included capturing dozens of prizes, taking over a million dollars in goods and specie, suffering accusations of piracy, enduring multiple lawsuits, gaining citizenship in two foreign countries, striking up a friendship with the future president of Venezuela, becoming a commodore in the Colombian navy, losing his squadron in battle, and sitting in a Spanish jail as a prisoner of war before coming home to Baltimore and retiring from the sea a prosperous man, praised in South America for his aid to the cause of independence and esteemed in Baltimore as a respectable citizen. ${ }^{4}$

In light of their transformation amid fighting for a cause of national liberation, it is natural to inquire what liberty meant to Captains Almeida, Chaytor, and Danels. And yet

3 Baltimore Price Current, 10 August 1811, 10 October 1811, 19 October 1811, 9 November 1811, 28 December 1811, 1 April 1815, 20 May 1815, 7 October 1815; Commercial Advertiser (New York), 17 March 1817; deposition of Laurence Maddeson, U.S. v. Irresistable, Admiralty Case Files, United States District Court for Maryland (Baltimore), Records of District Courts of the United States, Record Group 21, National Archives and Records Administration-MidAtlantic Region (Philadelphia) (hereafter: DCMD, Adm.); depositions of Charles Staples and Joseph Atkinson n.d., Depositions Regarding Baltimore Privateers in South American Waters, Records on Privateers and Pirates, 1813-1835, General Records of the Department of State, Record Group 59, National Archives at College Park, MD (hereafter: College Park Depositions); Fred Hopkins, "For Flag and Profit: The Life of Commodore John Daniel Danels of Baltimore," Maryland Historical Magazine LXXX (1985), 393-394.

4 James Chaytor to Sarah Chaytor, Maryland Historical Society, James Chaytor Papers, 10 June 1818 (hereafter JCPM); Joseph Almeida to Charles K. Mallory, U.S. v. The Brig Wilson, Admiralty Case Files, United States District Court for the Eastern District of Virginia (Norfolk), Records of District Courts of the United States, Record Group 21, National Archives Microfilm Publication M130, Admiralty Case Files of the U.S. District Court for the Eastern District of Virginia, 1801-1861 (hereafter: DCVA, Adm.); Fred Hopkins, "For Freedom and Profit: Baltimore Privateers in the Wars of South American Independence," The Northern Mariner/le marin de nord XVIII (2008), 93-104; David Head, "Baltimore Seafarers, Privateering, and the South American Revolutions, 1816-1820, Maryland Historical Magazine CV (2008), 269-293; David Head, "Sailing for Spanish America: The Atlantic Geopolitics of Foreign Privateering from the United States in the Early Republic" (Unpublished Ph.D. thesis, State University of New York at Buffalo, 2009), appendix D. 
such a question, what liberty meant to sea captains, is rarely asked by maritime historians, who have focused much more often on what liberty meant to common sailors. Indeed, common sailors have become largely synonymous with maritime history itself. Even in the wake of important scholarship on captains' ideology and careers by Toby Ditz and Daniel Vickers and Vince Walsh, the men on the quarterdeck most often enter the narrative from the outside as foils against whom Jack Tar strives. In one case, captains are literally demonized. The devil of Marcus Rediker's Between the Devil and the Deep Blue Sea is the captain who represented the capitalist order at sea. Less dramatic but no less revealing of the current state of maritime history are historiographic reviews that take for granted that maritime history is synonymous with common sailors. But this need not be the case. ${ }^{5}$

Following the careers of Captains Almeida, Chaytor, and Danels provides one glimpse into the social and cultural history of captains. An abundance of sources document the lives of these men, making it possible to reconstruct large portions of their careers before, during, and after their participation in the Spanish American Wars of Independence.

5 For discussions of the meaning of liberty to common sailors, see Jesse Lemesch, "Jack Tar in the Streets: Merchant Seamen and the Politics of Revolutionary America," William and Mary Quarterly XXV (1968), 371-407; Daniel Vickers, "An Honest Tar: Ashley Bowen of Marblehead," The New England Quarterly LXIX (1996), 532-553; Margaret S. Creighton, Dogwatch and Liberty Days: Seafaring Life in the Nineteenth Century (Salem, MA: Peabody Museum, 1982); Marcus Rediker, Between the Devil and the Deep Blue Sea: Merchant Seamen, Pirates, and the Anglo-American Maritime World, 1700-1750 (Cambridge: Cambridge University Press, 1993); Marcus Rediker and Peter Linebaugh, The Many-Headed Hydra: Sailors, Slaves, Commoners, and the Hidden History of the Revolutionary Atlantic (Boston: Beacon Press, 2002); Paul Gilje, Liberty on the Waterfront: American Maritime Culture in the Age of Revolution (Philadelphia: University of Pennsylvania Press, 2004). For literature reviews that discuss common sailors but not captains, see Daniel Vickers, "Beyond Jack Tar," William and Mary Quarterly L (1993), 418-424; Matthew Raffety, "Recent Currents in the Nineteenth-Century Maritime History," History Compass VI (2006), 607-626); Paul Gilje, "The Illusive Jack Tar," in Pirates, Jack Tar, and Memory: New Directions in American Maritime History, ed. Paul Gilje and William Pencak (Mystic: Mystic Seaport Museum, 2007), 1-10. For other recent statements in Age of Sail American maritime history that likewise focus on common sailors, see W. Jeffrey Bolster, Black Jacks: African American Seamen in the Age of Sail (Cambridge, MA, 1997); Myra C. Glenn, Jack Tar's Story: The Autobiographies and Memoirs of Sailors in Antebellum America (New York, 2010); Glenn, "Forging Manhood and Nationhood Together: American Sailors' Accounts of Their Exploits, Sufferings, and Resistance in the Antebellum United States," American Nineteenth Century History VIII (2007), 27-49; Glenn, "Troubled Manhood in the Early Republic: The Life and Autobiography of Sailor Horace Lane," Journal of the Early Republic XXVI (2006), 59-93; Evan Lampe, “The Most Miserable Hole in the Whole World': Western Sailors and the Whampoa Anchorage, 17701850," International Journal of Maritime History XXII (2010), 15-40. For investigations of captains, see Toby Ditz, "Shipwrecked; or, Masculinity Imperiled: Mercantile Representations of Failure and the Gendered Self in Eighteenth-Century Philadelphia," Journal of American History LXXXI (1994), 51-80; Daniel Vickers and Vince Walsh, Young Men and the Sea: Yankee Seafarers in the Age of Sail (New Haven, CT, 2005). For an examination of common sailors and merchants, see Christopher P. Magra, The Fisherman's Cause: Atlantic Commerce and Maritime Dimensions of the American Revolution (New York, 2009). 
Doing so allows us to inquire what one kind of liberty - the independence of Spanish America - meant to one type of captain - merchant captains who turned to privateering. For these men, liberty meant the political independence of the emerging nations they served, as well as the opportunity for greater personal and financial independence. The Spanish American service promised these three men a cause worth fighting for and a chance to achieve greater distinction than they could at home. Yet although the new nations gained their independence, only Captain Danels achieved the personal independence he sought. $^{6}$

\section{Captains}

Becoming a captain was a notable achievement. At the pinnacle of their profession, captains were respected members of the commercial world, and, with the superior earning power their position afforded, they could support a family and even enjoy a few of the finer things in life as well. They might even enter the ranks of the elite, if they were lucky. By the nature of their position, then, captains such as Almeida, Chaytor, and Danels possessed greater independence than many of their contemporaries, and yet their position was often precarious. A bad voyage, a bad family situation, or simple bad luck could plunge them into penury and dependence. As a result, resourcefulness and adaptability were crucial to winning and keeping the independence to which their position afforded access. ${ }^{7}$

Of the three, Captain Chaytor had the most varied early career. Born in 1775 or 1776 in Virginia, Chaytor was master of a ship by 1800 when he sailed the schooner John from Baltimore to Havana. He may have become a captain several years prior since his first child, Eliza, was born in 1794. Captains often married and started their family soon after receiving their first command, but at eighteen or nineteen in 1794, Chaytor would have been extremely young for a sea captain. At twenty-five in 1800, he would have been closer to the norm. Whatever the case, Chaytor's pocketbook pressures had already started. In 1798, Chaytor had a son, too: James, Jr. ${ }^{8}$

Chaytor took several ships to Caribbean destinations. He sailed the brig

6 My approach to tracking the careers of seafarers follows from Vickers, "Honest Tar."

7 For the social status of captains, see Jerome Garitee, The Republic's Private Navy: The American Privateering Business as Practiced by Baltimore during the War of 1812 (Middleton, CT, 1977), 65; Gary B. Nash, The Urban Crucible: Social Change, Political Consciousness, and the Origins of the American Revolution (Cambridge, 1979), 20-21; Vickers and Walsh, Young Men and the Sea, 121-123. As a counterpoint to the kind of life a Baltimore captain could expect, see Seth Rockman, Scraping By: Wage Labor, Slavery, and Survival in Early Baltimore (Baltimore, 2008).

8 Protection Certificate, schooner John, Historical Society of Delaware, James Chaytor Papers, 23 June 1800. W.G.D. Worthington to John Quincy Adams, 7 March 1819, Diplomatic Correspondence of the United States Concerning the Independence of the Latin-American Nations ed. William R. Manning (3 vols., New York, 1925-1926), 1: 523-525; Chaytor to Worthington, 14 December 1826, JCPM. Baltimore Patriot, 23 June 1834; Vickers and Walsh, Young Men and the Sea, 113-117. 
Greenwhich to Martinique in 1806 and navigated the schooner David on two voyages to Vera Cruz in 1807. European ports of call also figured into Chaytor's work, and he completed trips to Harve de Grace, France, in the John in 1802 and to Bordeaux in the ship Stratford two years later. He also visited destinations farther afield: the Isle of France, modern-day Mauritus in the Indian Ocean in 1805, and the Turkish port of Smyrna in 1811. The latter voyage emerges from Chaytor's papers in tantalizing secrecy. Baltimore merchant Thomas Tenant approached Chaytor about a "matter of confidence," taking his brig Herald from London to the Mediterranean. Given his desire for discretion, it is possible Tenant hoped to ship opium. Whatever the case, the voyage was a bust. Chaytor arrived to a dismal market and disposed of the Herald's cargo as best he could. ${ }^{9}$

The year 1808 brought a daunting challenge to Chaytor, as it did to all ocean-going sailors: President Jefferson's embargo. But while others sat idle on the nation's docks, Chaytor broke the law, sneaking out of port in the schooner John, bound for Laguaira on the Spanish Main. Chaytor acquired a cargo of coffee and indigo and delivered it to Livorno, a Mediterranean port in Tuscany, at the time controlled by France. Arriving in August, Chaytor was sequestered by French authorities for violating the Bayonne Decree, which aimed to interdict British trade to the Continent. The law held that since the United States had embargoed its foreign merchant marine, any captain arriving at a Continental port and claiming to be American must be lying to conceal the vessel's true British identity. Chaytor spent the next two years stranded in Livorno, and although there are worse places to be stuck than a Tuscan seaport, any of the city's charms were lost on Chaytor as he was periodically interrogated by the U.S. consul, who intended to proceed against the vessel for violating the embargo if the French did not seize it first. Chaytor admitted his own misdeeds- "I knew well I was violating the law of the U. States in departing from the port of Baltimore," he confessed - but he refused to incriminate anyone else. Unable to secure the John's release, the frustrated captain left Italy at the end of $1810{ }^{10}$

After returning home, Chaytor had an uneventful war with Britain. He commanded the galley Vigilant in the Chesapeake, and afterwards, he sailed the letter-of-marque trader Expedition between Newport, Rhode Island, New York City, New Orleans, and Bordeaux, capturing three British vessels along the way. Chaytor strove to achieve the independence

9 For Chaytor's voyages, see John Docurnaus to Chaytor, 17 September 1804; shipping manifest, ship Chesapeake, 13 September 1805; receipt, schooner David, 26 November 1807; Thomas Tenant to Chaytor, 29 May 1811; Certificate for Foreign Ships, brig Herald, 27 August 1811; Chaytor to John Kervan and Sons, 4 October 1811, 18 October 1811, JCPP; Ship's papers, brig Greenwhich; Clearance Papers, schooner David, JCPM; Philadelphia Gazette and Daily Advertiser, 7 April 1802; New-York Evening Post, 17 September 1807.

10 Quote: Chaytor quoted in Thomas Appleton to John Armstrong, 6 September 1808, Despatches from United States Consuls in Leghorn, 1793-1906, National Archives Microfilm Publication T214, roll 2. See also depositions of Thomas Simpson, 15 November 1808, William Saxton, 16 November 1808, and Robert Stoddard, 21 November 1808; Thomas Appleton to John Armstrong, two letters dated 11 November 1808; Appleton to James Madison, 26 November 1808; Appleton to James Monroe, 2 December 1808, all in ibid. For the Bayonne Decree, see Anna C. Clauder, American Commerce as Affected by the Wars of the French Revolution and Napoleon, 1793-1812 (1932; rep., Clifton, NJ, 1972), 11. 
of a successful sea captain, but, again and again, he came up short. Though clearly trusted by ship owners and able to find steady work, he found poor markets and restrictive laws checking his advance. At the same time, Chaytor's actions imply a possible political significance - breaking a controversial law, transporting a secret cargo, accepting a United States commission. Yet, Chaytor left no trace of his political opinions. ${ }^{11}$

Captain Almeida's early career reversed the pattern of Captain Chaytor's experience: a mundane pre-war life followed by adventurous conflict with the British. Born a Portuguese subject in the Azores, Almeida became master of the Portuguese brig Pastor in 1803. His voyages included stops in Baltimore, and it seems that on one of them he met a good Maryland girl since he soon married, settled in town, and, in 1805, became both a father and a U.S. citizen. As an American merchant captain, Almeida's fortunes rose steadily. He made regular voyages to Cuba - mostly to Havana, sometimes to St. Jago, and, for a little variety, Trinidad on the island's underbelly, as well. The workload was heavy. Between 1806 and 1812 Almeida completed at least twenty-three voyages, even though he was inactive in 1808 due to the embargo. At times, he would shuttle back and forth in a month, unloading one cargo at Baltimore and heading right back to sea. But it paid off. In 1806, Almeida registered his own vessel, the schooner Mary, which he replaced in 1810 with another schooner of his own, the New Mary. Two years later, Almeida could afford a second vessel, the schooner Joseph and Mary, and the two sailed together for-where else?-Cuba. ${ }^{12}$

Within the war's first months, Almeida sold the Joseph and Mary to a group of investors seeking a fast vessel for privateering. Though he did not command, Almeida

11 Chaytor to Thomas Tenant, 23 May 1812, and to Purviance, 3 September 1812, 29 September 1812; James A. Buchannan to Chaytor, 26 May 1813; unidentified to Chaytor, 8 June 1813; Daniel Chaytor to James Chaytor, 8 September 1813; C.F. Visinier to Chaytor, 11 June 1814; Crew List, brig Expedition, 17 September 1814, JCPP; Newport Mercury, 28 August 1813; Baltimore Patriot, 12 December 1814.

12 Elizabeth Rice Seim's family history gathers together valuable genealogical information on Almeida. See A History of Joseph Almeida and His Family (Alexandria, VA, 1991). For the change in citizenship, see Garittee, Republic's Private Navy, 101. Almeida's movements can be tracked via the shipping news of several newspapers: Baltimore Price Current 26 June 1806, 13 November 1806, 25 December 1806, 8 January 1807, 5 March 1807, 19 March 1807, 20 August 1807, 12 November 1807, 24 December 1807, 24 December 1808, 11 February 1809, 18 March 1809, 8 July 1809, 28 April 1810, 12 May 1810, 5 October 1811, 4 January 1812; New York Commercial Advertiser, 19 November 1803, 20 April 1804, 28 July 1806, 29 September 1806, 7 September 1809, 23 December 1809, 3 August 1811; New York Mercantile Advertiser, 8 September 1806; New York Price Current, 4 July 1807, 21 November 1807; New York Gazette, 11 May 1809; Baltimore Federal Republican, 29 May 1809, 27 June 1809, 3 July 1810; American Citizen (New York, NY), 9 November 1809; American Watchman (Wilmington, DE), 15 February 1812; Boston Gazette 2 March 1812. In the Sereno case, James McCulloch testified that Almeida registered these vessels in 1806, 1807, and 1810, respectively. See deposition of McCulloch, n.d., The Sereno, Appellate Case Files of the U.S. Supreme Court, 1792-1831, Records of the Supreme Court of the United States, Record Group 267, National Archives Microfilm Publication M214, Appellate Case Files of the Supreme Court of the United States, 1792-1831, case nos. 994-996. 
retained a share as owner. A year later, Captain Almeida began the first of two cruises in the privateer Caroline, sailing from Charleston and returning with twenty enemy vessels all told. Almeida's next command, the Kemp, proved even more successful and earned him a name for boldness. Taking the helm at Wilmington, North Carolina, Almeida attacked a convoy of eight British merchantmen and a Royal Navy frigate, capturing four prizes. By war's end Almeida had captured thirty vessels, making nearly $\$ 300,000$ for his owners and almost $\$ 46,000$ for himself - nearly $\$ 700,000$ in 2011 dollars. At the same time, Almeida suffered a significant loss. His wife, Ann, died while he was at sea in February 1814, leaving their four children without a mother. However, Almeida soon found a new woman, Teresa, whom he married that summer and began adding more children to the family. ${ }^{13}$

In this phase of life Almeida appears to have advanced toward financial independence at the same time that personal tragedy and a growing family would have made that pursuit more precarious and urgent. As with Captain Chaytor, some of Almeida's actions suggest a possible political motive, such as his naturalization as a U.S. citizen or his acceptance of a privateering commission, although the evidence is silent on his precise motivations. Both actions may have simply been ways to advance his career.

Though younger than the others, Captain Danels was not inexperienced in the ways of commanding a ship before the War of 1812. Born in 1783 in Maine, Danels sailed on his maiden voyage as master in 1811, and for the next year he followed a regular route between Baltimore and Haiti with the schooners Wolf and Eagle. During the war, Danels commanded three vessels. The Eagle and the Rossie, both letter-of-marque traders owned by the firm D'Arcy and Didier, were captured by the Royal Navy. Danels became a prisoner of war, first in Bermuda and then in Plymouth, England. Nevertheless, D'Arcy and Didier maintained enough confidence in their captain to put him in charge of yet another vessel, the Delille, also a letter-of-marque trader. From November 1813 to November 1814, Danels avoided His Majesty's Navy but found several of His Majesty's merchant ships, taking at least eight as prizes. With this success, D'Arcy and Didier converted their vessel to a privateer, now called Syren, which Danels lost while returning to the United States trying to evade a British blockade. In spite of the loss of three vessels, Danels emerged from the war on his feet and heading upwards. Only a handful of U.S. privateer captains owned a share of the vessels they commanded, and Danels was one of them. Whatever prizes managed to get into port safely, he received a captain's share when the prize money was divided as well as an investor's share of the profits at the end. ${ }^{14}$

Once Chaytor, Almeida, and Danels began sailing as captains, it becomes possible

13 Baltimore Patriot, 24 February 1814; Geographical and Military Magazine (New York), 14 March 1814; John McManemin, Captains of the Privateers of the War of 1812 (Spring Lake, NJ, 1994), 50-54; Garitee, Republic's Private Navy, 36, 39, 135, 158, 212, 252, 254; Seim, Joseph Almeida, viii.

14 Baltimore Price Current, 10 August 1811, 19 October 1811, 9 November 1811, 28 December 1811, 12 March 1812, 23 May 1812, 5 December 1812, 28 May 1814; Baltimore Patriot, 12 March 1813, 12 March 1814; Norwich (CT) Courier, 3 June 1812, 20 April 1814; Boston Daily Advertiser, 25 March 1814; The Repertory (Boston), 21 April 1814; New York Commercial Advertiser, 12 May 1814; Hopkins, "For Flag and Profit," 393-394; Garitee, Republic's Private Navy, 36, 220. 
to track them through the shipping news that was a staple of the early nineteenth century press. Ship's papers, court cases, and personal letters that have survived provide additional information. From these sources, the captains appear as men striving to improve their economic lot. They traveled the Atlantic and Caribbean delivering cargoes and, when war came, endeavoring to capture the enemy's merchant vessels. In these respects little distinguishes the three from their contemporaries. They did what many other American sea captains did. Spanish America's struggle for independence - the cause that would come to dominate their lives - still lay in the future.

\section{Spanish America}

Each man returned to the merchant marine following the War of 1812. For the three captains it was some misfortune that forced each of them to seek a new career. Danels wrecked his ship. Almeida was arrested transporting a cargo to Cartagena. Chaytor found a dismal market in Buenos Aires. Nevertheless, each captain found something appealing in Spanish America once they began sailing as privateers. They came to identify with the cause, and the benefits it might bring them, until they were no longer typical American sea captains.

Chaytor respected the government of the United Provinces by running a tight ship aboard his vessel, the Independencia del Sud. He kept a close eye on expenses. Amongst his papers are two account books for the vessel that record the daily use of provisions; note the stores used by the bosun, sailing master, gunner, and carpenter; and account for the money paid to officers and crew. The books also list the weekly "bill of fare": beef and flour on Sunday, pork and peas on Monday, beef and beans on Tuesday, and so on through the week. Between 1816 and 1820, Chaytor made four cruises and captured at least two dozen vessels including the Royal Philippine Company's million-dollar Esperanza, taken in tandem with another privateer. When the prize arrived at Buenos Aires, it took four weeks to unload. ${ }^{15}$

Chaytor paid careful attention to the rules governing the entrance of foreign warships when docking at a U.S. port. Ending an 1817 cruise at Norfolk, he presented himself as an officer of the Buenos Aires Navy commanding a public vessel of war, duly commissioned by a belligerent government. Chaytor showed Customs Collector Charles K. Mallory his commission, sailing orders, log book, and "a list of the armament and warlike equipment, crew, stores, \& merchandize of the sloop of war Independencia del Sud" that detailed the guns, small arms, crew, and prize goods brought in by Chaytor's vessel. He had done much the same in October 1816 when entering Baltimore for repairs. Chaytor had his vessel's arms, ammunition, and cargo removed under a customs officer's supervision, and once repairs were completed, everything was put back aboard while one of Chaytor's lieutenants submitted a report to the customs house showing that no new arms had been added. ${ }^{16}$

15 Records of the Independencia, JCPP; deposition of John Peckner, 16 July 1818, Thomas Stoughton v. James Barnes, NY Adm.

16 Mallory to Crawford, 22 March 1817; List of Armaments, n.d., Pablo Chacon v. Eighty-Nine Bales of Cochineal, Three Bales Jalap, and One Box Vanilla, DCVA, Adm.; The Santissima 
Chaytor was similarly precise and formal in his legal proceedings. In one instance, Chaytor responded to a lawsuit by claiming that "open and public war \& hostilities" existed between the United Provinces and Spain, that the Independencia was a public vessel of war, and that he was properly commissioned, instructed, and empowered to attack Spanish vessels. That he did attack Spanish vessels, Chaytor made no secret. On the contrary, he provided the exact locations: $22^{\circ} 45^{\prime} \mathrm{N}, 85^{\circ} \mathrm{W}$ for the prize Santissima Trinidad and $23^{\circ}$ $40^{\prime} \mathrm{N}, 85^{\circ} 18^{\prime} \mathrm{W}$ for the prize Santander. Finally, Chaytor emphasized that he entered Norfolk regularly and deposited his prize cargo in the public storehouse under the government's care. Chaytor's son-in-law, W.G.D. Worthington, did not approve of his thoroughness. As the case was appealed and more responses were needed, he recommended making only a general denial, thereby putting the burden of proof back onto the libellant. "The fewer [words] we use in such contexts as these, the better," he advised. ${ }^{17}$

Over time, Chaytor identified more and more with his adopted country and its cause. Worthington, himself an enthusiastic supporter of Latin American independence, admired Chaytor's exertions. "By birth, education, \& habit, [we are] the sons of liberty, the advocates of the Rights of Man throughout the Globe," Worthington wrote to Chaytor, from the captain's home in Baltimore, "and each of us, tho' on different elements, [are], I hope, destined to play no inferior part in the great political Drama that is now acting in the South." 18

Chaytor embraced the name Diego. At times, he presented himself to U.S. officials as Commodore Diego Chaytor, no doubt to emphasize that he was no longer a U.S. citizen. Other privateer captains acted similarly, deploying a Spanish name when it suited them, but Chaytor took his Diego identity to heart. While in Buenos Aires, he wrote to his wife, Sarah, signing the letter "DC." Later, in the 1820 s, Chaytor wrote a series of letters to potential business partners in Venezuela, both Americans. Sometimes he signed JC. Other times he signed DC. He had no reason to fool these men. He simply slipped back and forth between names, unconsciously identifying himself as both an American and a Spanish American. ${ }^{19}$

For all his devotion and fastidious official conduct, Chaytor had secrets. $\mathrm{He}$ claimed the Independencia was a public man-of-war, owned by the government of Buenos Aires, but when he converted the vessel from the merchantman Mammoth to the Independencia he actually sold it to himself and two others. Chaytor's eagerness to comply with some customs procedures belied his resistance to others. While in Norfolk in 1817,

Trinidad (1822), 20 U.S. 283.

17 Claim of Chaytor, 22 April 1817, Chacon v. Eighty-nine Bales; W.G.D. Worthington to Chaytor, 2 February 1820, JCPP.

18 Worthington to Chaytor, 29 March 1817, JCPM. See also David Head, "New Nations, New Connections: Spanish American Privateering from the United States and the Development of Atlantic Relations," Early American Studies 11 (2013), 161-175.

19 Chaytor to Mallory, 17 April 1817, JCPM; claim of Chaytor, 22 April 1817, Chacon v. Eighty-nine Bales; Chaytor to Sarah Chaytor, 10 June 1818, JCPM; Chaytor to Robert K. Lowry and John Myers, 10 October 1825, 10 November 1825, 10 December 1825, 20 December 1825, 20 January 1826, 1 March 1826, JCPP. 
Chaytor received a letter-marked "Confidential" - advising him how to get prize goods into the country. "I am confident that Prize Goods cannot be entered at the Port of Folly Landing," observed L.D. Teackle, a contact from Somerset County, Maryland. "The Collector understands his business too well, \& will not depart in any respect from the most strict \& rigid observance of the Law - but the case is entirely different at the Port of Snow Hill." Another informant, William Stewart, offered instructions on how to use Amelia Island in Spanish Florida to safely smuggle goods or to equip for his next cruise. Stewart urged Chaytor "to see Mr Y the very first thing you do after you leave port as I am of opinion you can get any thing and every thing safe through that channel if you are only cautious not to awaken suspicion." 20

These evasions helped Chaytor profit from his cruises, and complying with some elements of the law to facilitate the violation of others was a common tactic of Spanish American privateers operating illegally from the United States. At the same time, profits, even if obtained illegally, allowed Chaytor to serve the cause of independence, especially since the United Provinces had been slow in paying Chaytor the proceeds of his cruises. "I am almost worn out with delay and disappointment," he once wrote to Sarah from Buenos Aires. "Not a month has passed since my arrival here that I have not had some just cause to hope it would be my last." A year later, he was still unhappy. "My ambition to promote the cause of La Plata has completely ruined me," he lamented to Guy. "I have, since I joined the glorious cause of South America, armed four vessels in its defence [;] I have sacrificed my fortune to its greatness - had I millions it should be employed in its cause." But Chaytor did not have millions of dollars. He had to sell a new chronometer to pay for son George Washington Chaytor's schooling and his subscription to the Baltimore American went unpaid for years. Chaytor had only millions of worries. ${ }^{21}$

Chaytor had found in Spanish America a cause the provided him with a sense of importance. Surely he hoped to bask in the glow of the "glorious cause of South America," and by risking his life for the cause, it would have been a pride justly felt. At the same time, Chaytor also believed his efforts would prove financially rewarding. Thus far, Chaytor's years of dedicated service - and the capture of several rich prizes - helped advance the independence of Spanish America but his own independence lagged behind.

Of the three captains, Joseph Almeida stated his motives for becoming a Spanish American privateer most clearly. He wanted revenge. "Cartagena [is] ever memorable to me by the cruelties which I received from [Spanish General] Morillo and his army," Almeida once wrote. "I lost my property, suffered imprisonment and was discharged with my life only." Almeida's time in a Spanish prison had embittered him. "Resentment for lost property and personal injury," he said, "carried me into the South American

20 L.D. Teackle to James Chaytor, 27 March 1817; William Stewart to Chaytor, 13 April 1817, JCPM. See also The Santissima Trinidad, 20 U.S. 283; W.G.D. Worthington to John Quincy Adams, 7 March 1819, in Manning, Diplomatic Correspondence of the United States, 1: 523 525.

21 Chaytor to Sarah Chaytor, 10 June 1818, JCPM; James Chaytor to Adam Guy, 30 November 1819, JCPM. James Chaytor Diary, 14 March 1821; Baltimore American receipt, 1824; Chaytor to Asa Homer, 24 August 1820, and to unidentified, 16 September 1820, JCPP. 
service." 22

Between 1816 and 1820, Almeida completed five cruises, during which he commanded three vessels: Congresso, Louisa, and Louisa Cosary, later renamed the Wilson and then the Bolivar. Almeida netted at least $\$ 47,000$ from these outings, and by 1818 he again owned two vessels at the same time: the brig Wilson, commanded by Ivory Huntress and the schooner Almeida, commanded by George Wilson. (Almeida never did, as would have been fair, command a vessel named Huntress. $)^{23}$

Almeida followed the rules of privateering when he needed to. He became a citizen of the United Provinces, and he received a commission from its government and, later, one from Venezuela. He sent some prizes into port for condemnation. He swore to Norfolk Customs Collector Mallory that he had instructed his agent to "request the custom house to send an officer on board [the Wilson] to prevent smuggling." But Almeida also put his own interests first. For example, in 1816 the government Buenos Aires asked Almeida to help exile a troublesome journalist, who had criticized the government, by transporting him to Haiti.That winter Almeida had plenty of time to stop at Haiti while cruising the Caribbean, but he concentrated on privateering instead and never completed the task. ${ }^{24}$

Almeida was a poor leader who frequently provoked his crews to mutiny. The affair of the Louisa in 1818 was typical. Trouble began as the vessel left the Chesapeake and Almeida gathered the crew to sign the ship's articles of war. Almeida had billed the Louisa as a sealing vessel bound for the Pacific Northwest. Some men resented the change. Others objected to the size of the prize shares Almeida offered to common sailors. Almeida quieted the discontent with stealthy violence. He relented at first and mollified the crew by sending them to dinner. Then he called the most vocal malcontents up to the deck, one at a time. The officers beat the men, put them in chains, and threw them into a make-shift jail. The other men got the message, for the moment. Almeida extricated himself from the volatile situation when he took charge of a prize himself, rather than turning her over to a prize master, and sailed away. With the remaining officers left vulnerable, a mutiny soon followed. Almeida left just in time. ${ }^{25}$

22 Quote: Joseph Almeida to Mallory, 6 November 1819, U.S. v. The Brig Wilson, DCVA, Adm.

23 Invoice of sales, 21 November 1818, John B. Bernabeau v. The Arrogante Barcelonis, DCMD Adm.; Almeida to Mallory, 6 November 1819, U.S. v. The Wilson, DCVA, Adm.; libel of Bernabeau, 6 November 1819, John B. Bernabeau v. The Cargo of the Armed Schooner Almeida; Benjamin Keen, David Curtis De Forest and the Revolution of Buenos Aires (New Haven, CT, 1947), 115.

24 Quote: Almeida to Mallory, 6 November 1819, U.S. v. The Brig Wilson, VA, Adm. See also Lewis Winkler Bealer, "The Privateers of Buenos Aires, 1815-1821: Their Activities in the Hispanic American Wars of Independence" (Unpublished Ph.D. thesis, University of California, Berkley, 1935), 57-58.

25 Charles Fullerton, A Circumstantial Account of the Occurrences that took place during the Cruise of the Ship Louisa; Which Sailed from Baltimore under the Buenos Ayrean Flag, Commanded by Joseph Almeida; relating, at length, The Mutiny, with the Subsequent Events; and the Invasion of the Isles of Bonavista and Mayo, by the Bucaniers who composed her crew. To Which is Added the Confession of Henry Robert Wolfe, and an 
Revenge is not really an ideological motivation, and it is hard to believe that personal animosity alone sustained Almeida through his many cruises as a privateer. Certainly he needed to provide for his family and taking prizes promised a lucrative return. Almeida's personality and character, however, frustrated his hopes for financial independence even as it blunted the impact he may have had on hastening the decline of his enemy's empire.

John Danels was a relative latecomer to Spanish American privateering. While Almeida and Chaytor made their first cruises and captures, Danels sailed on voyages to France and Haiti. The shipwreck changed all that, and Danels began privateering, sailing his new command, the brig Vacunia, for Buenos Aires in March 1818. He obtained a commission from the Oriental Provinces of the Río de la Plata (what would become Uruguay), which was at war with both Spain and Portugal. He renamed his vessel Irresistable and went to work. Between July and September 1818, he captured two dozen vessels large and small, all Portuguese except for one Spanish schooner. Danels cruised between Brazil and Africa, where he could intercept the richly laden ships trading between Rio de Janiero and Lisbon while also preying on the enormous East Indiamen carrying specie and spices between Portugal and its colonies on the subcontinent. The Portuguese consul alleged that $\$ 90,000$ worth of cotton, tea, ginger, salt peter, and cinnamon were taken from the brig Globo, bound to India, and forty boxes of gold and thirty bags of silver worth $\$ 400,000$ were taken from the ship Asia Grande. For other vessels, the consul reported lost specie in amounts of $\$ 26,000 ; \$ 11,000 ; \$ 10,000$; and $\$ 7,000$. All told, Danels made off with $\$ 1.5$ million in Portuguese property-worth an eye-popping \$24 million today. ${ }^{26}$

Danels sailed very close to the edge of the rules of private armed warfare, especially when obtaining a proper commission. On first leaving Baltimore, the Vacunia sailed directly to Buenos Aires. Not only did Danels refuse to put into any port or capture any vessels on the way but he also refrained from stopping to speak to any passing ships as friendly captains so often did. Danels did, however, hone his crew's fighting skills,

Account of his Execution, along with George Clark (Charleston, 1820), 7. See also depositions of Henry Trigger, 25 March 1819, John B. Bernabeau v. The Brig Arrogante Barcelonas, MD Adm.; The Particulars of the Piracies; Committed by the Commanders and Crews of the Buenos Ayrian Ship Louisa, and those of the Sloops Mary, of Mobile, and Lawrence, of Charleston; Wherein is Accurately Described the Murder of Capt. Sunley, and Four of the Crew of the British Brig Ann. Collated from the Statements Given by the Bucaniers who have been Apprehended and Confined in Charleston Gaol, Some of Whom Have Since Become State's Evidence; with the Time of Their Arrest, Trial, Condemnation, or Discharge, and Some General Observations (Charleston, 1820).

26 Libel of John B. Bernabeau, 21 April 1819, John B. Bernabeau v. The Brig Nereyda and John Danels, MD Adm.; libel of William R. Swift, 15 April 1819, William R. Swift v. John D. Daniels for the Illegal Capture of the Portuguese Brig Globo and Cargo, and Other Vessels, DCMD Adm.; deposition of Andrew Lindborn, 20 April 1819; Charles Staples and Joseph Atkinson, n.d., College Park Depositions; Poulson's American Daily Advertiser (Philadelphia), 28 September 1818; (New York) Commercial Advertiser, 28 September 1818; Augustin Beraza, Los Corsarios de Artigas (Montevideo, 1949), appendix. 
calling the men to quarters and practicing their gunnery. In Buenos Aires, he discharged the crew, dismantled the ship, and sold it to the government. Having given over his ship to the United Provinces, Danels next made himself a part of it, too, by becoming a naturalized citizen. Now, with a commission for his vessel, to be called the Maipu after General José de San Martín's recent victory at the Battle of Maipú, Danels was ready for sea. However, he changed his mind about serving Buenos Aires and secured an Oriental commission. Holding two commissions at the same time was illegal, according to both international law and the Buenos Aires prize code, and officials at Buenos Aires caught wind of Danels' double-dealing. Just prior to sailing, several officers boarded his vessel for an inspection. Danels denied holding two commissions, and when asked to take a complement of Buenos Aires marines along for the cruise, he readily agreed, promising to wait for them to come aboard the next day. Danels sailed that night, leaving the marines behind. He returned the Buenos Airean commission via a ship he passed on the River Plate, but officials were still upset. They declared him "a Pirate and a sea Robber," as the Portuguese consul later recorded, and seized the $\$ 10,000$ bond posted by Danels' armador, William P. Ford. Now persona non grata in the United Provinces, Danels never returned. ${ }^{27}$

Nevertheless, Danels had big plans for his career, and took to calling himself Commodore Danels. While visiting Margarita, an island off the coast of Venezuela, he joined a Venezuelan admiral in planning an attack on a nearby port held by the Spanish using the Irresistable and a recent prize, the Nereyda. Danels' Venezuelan project seems calculated to advance his own interests more than those of anyone else. He certainly took little notice of his men. While in Margarita, Danels shanghaied the crew of the Buenos Aires privateer Creola, demanding that they enlist aboard his ships or be thrown in jailif he did not first "hoist them to the yard arm," as one of the Creolla's sailors said. The men took matters into their own hands, seizing control of their ship, rowing over to the faster-sailing Irresistable, which lay nearby, surprising her officers and crew, and making their escape while Danels, spending the night on shore, frantically gave chase in the Nereyda. ${ }^{28}$

27 Decree and opinion of Bland, Bernabeau v. Nereyda, MD Adm.; depositions of Samuel Beaver, 27 November 1819 and Laurence Maddeson, 29 November 1819, U.S. v. Irresistable, DCMD Adm.; deposition of Andrew Lindborn, 20 April 1819; Charles Staples and Joseph Atkinson, n.d., College Park Depositions; libel of William R. Swift, 15 April 1819, Swift v. Daniels, DCMD Adm.; Thomas Lloyd Halsey to William H. Winder, 30 September 1821 and Halsey to Henry Didier, 30 September 1821, Halsey letters in the Jonathan Meredith Papers, Library of Congress; "An Ordinance of the Government of Buenos Ayres, Regulating Privateers," 4 Wheaton, appendix 28; Rhode Island (Providence) American and General Advertiser, 5 February 1819; Hopkins, "For Flag and Profit," 395.

28 Quote: petition of John Ferguson, 20 May 1819, U.S. v. John Ferguson, MD Crim. See also Extracts from the Life of Captain John F. Ferguson, who was Executed in the City of Baltimore, on the Thirteenth Day of April, 1820 (Baltimore, 1820), 14-15; plea and claim of Childs, 29 April 1819, and opinion and decree of Bland, 3 January 1820, Bernabeau v. Nereyda; Alexandria (VA) Gazette and Daily Advertiser, 19 April 1819; Niles Weekly Register, 7 August 1819, 17 June 1820; National Register, 31 July 1819. 
For Danels, South America was a place where he could enjoy greater opportunity than he had found in Baltimore. He commanded multiple vessels, captured millions of dollars worth of Spanish and Portuguese property, and was set to take on an important role in the Venezuelan Navy. Achieving independence for Spain's former colonies helped Danels attain a greater position for himself.

\section{In the Colombian Service}

By 1822, the Patriots were on the cusp of a crucial victory in the war's northern theater. Driving the Spanish from the Main, the important cities fell to the Patriots one after another until only Puerto Cabello, a city in north-central Venezuela with an excellent port, and Maracaibo, in western Venezuela at the mouth of Lake Maracaibo, remained in Spanish control. The successes came as privateering from Baltimore declined. New neutrality laws, stricter enforcement, lawsuits, and the collapse of financing after the Panic of 1819 had combined to drive Spanish American cruisers out of the Chesapeake. Some Baltimore captains continued their service, with Chaytor, Almeida, and Danels among them. It seems that Spanish American independence and the personal independence privateering might secure still exerted a powerful influence on the captains. $^{29}$

Danels joined the service of Gran Colombia, a nation formed when the regions of the former Spanish New Grenada were combined into one state, and continued his ascent. Danels participated in a blockade of Cumana and Laguaira in 1821, and for his service he was granted Colombian citizenship and a commission in the navy. A year later, Danels traveled to the United States to buy a vessel for the Colombians. He took time to sit for a portrait. With a ship running before the wind in the background, Danels wears the uniform of the Colombian Navy and holds a card in his right hand inscribed "Commodore J.D. Danels / de la Marina / Naval de Colombia / a la Guyara." By 1823, Danels commanded a significant part of the republic's naval forces. He received official correspondence addressed to him as commander of "the Colombian Squadron." 30

Danels succeeded through luck as much as anything else. He still had a knack for losing vessels. In 1823 Danels, commanding the Carabobo, was on patrol with four other vessels when he descried the Spanish admiral's squadron, a forty-four and a forty-eight, guiding two merchantmen into Puerto Cabello, and although vastly outgunned, he attacked. And lost badly. Two vessels were surrendered, forty men were killed, and another 300, including the commodore himself, were taken into Puerto Cabello as prisoners. Fortunately, Danels' failure was reported in time for the Patriots to give up the blockade of Puerto Cabello and instead concentrate on attacking Maracaibo, where the shallow waters surrounding the city would neutralize the larger warships' advantage. The strategy worked. The Patriots captured Maracaibo in August, allowing them to resume the siege of Puerto

29 Head, "Baltimore Seafarers," 280-284.

30 William Dawkins to Danels, New York Public Library, Foreign Countries Miscellaneous Collection, 1572-1960, Central and South America Collection, 4 April 1823; Hopkins, "For Flag and Profit," 399. 
Cabello. This last Spanish stronghold in the north surrendered in November. ${ }^{31}$

Danels was supposed to interdict the Spanish shipping lanes. He not only failed to do so but he also lost his ships to the enemy, enhancing their strength. If the Patriots had not moved so decisively against Maracaibo, Spain's resistance could have continued. Yet Danels came out of it just fine. Though slightly wounded in the battle, he was paroled in weeks and by the time Puerto Cabello fell he was home in Baltimore, retired from the sea, and ready to enjoy his winnings. Danels had achieved personal independence, and Colombia achieved its independence, too. ${ }^{32}$

Chaytor also rose to a leadership position in the Colombian Navy, though at the end of his service he had nothing to show for it. In early 1821, Chaytor sent the Independencia out under a new captain while he stayed home in Baltimore for the next six months. Poor health may have been the reason since Chaytor complained of rheumatism in his left foot, and in more than twenty years, he had never been in port so long of his own volition. Chaytor kept a diary to occupy his time. He tracked the progress of the revolutions, the movements of his ship, and the activities of his fellow sea captains Danels and Almeida. From time to time, Chaytor interspersed personal observations, mostly about domestic squabbles. "Had a sharp disputation with Madam C. on the subject of her washerwoman's wages," he recorded on, of all days, 14 February. But by and large, the diary was a miscellaneous collection of things he must have read in the newspaper. One day he remarked on "the worshippers of the Hindus superstition" who numbered "500,000,000" worldwide and worshipped 330 million gods including "the cow, monkey [and] Serpent." Another day he observed that a man in England had won a bet by standing on one leg for four hours. On a third occasion he asserted that unicorns really did exist - one had been found "in the interior of Thibet." 33

Chaytor went back to sea in 1822, and he cruised again off Spain and off South America, but he could not quiet his anxieties about money. Chaytor complained to his wife, Sarah, about the "calamities, vicissitudes \& privations" he had experienced trying to get the Buenos Aires government to pay for his expenses. "The non payment of my Brig has deranged all my plans," he wrote, "and I fear the creditors frequently heap many maledictions on my head presuming that I only am to blame." He was right to be afraid. On returning to Baltimore in 1824, the Independencia's creditors sued, forcing Chaytor to seek bankruptcy protection. The Baltimore Patriot began running an "Insolvent Debtor" notice for Chaytor's creditors. ${ }^{34}$

31 Baltimore Patriot, 23 May 1823, 27 May 1823; Hopkins, "For Flag and Profit," 399; Jane Lucas De Grummond, Renato Beluche: Smuggler, Privateer, Patriot, 1780-1860 (Baton Rouge, LA, 1983), 211-224.

32 Baltimore Patriot, 24 June 1823, 1 September 1823. Danels to Joseph Lancaster, Historical Society of Pennsylvania, Simon Gratz Collection, Mexicans and South Americans, 16 September 1823.

33 James Chaytor Diary, 20 January, 24 January, 14 February, 11 March, and 31 March 1821, JCPP.

34 Quote: Chaytor to Sarah Chaytor, 18 October 1823, JCPM. See also Chaytor to Sarah Chaytor, 18 October 1823, JCPM; Chaytor to unknown, 9 February, 10 February, 1822; 
In 1825, Chaytor returned to South America, traveling there to become head of Colombia's marine department. Chaytor never formally occupied the office, however, as he was injured during an earthquake and, by the time he recovered, President Bolívar began cutting back the navy. Chaytor, fearing "the mortification of being laid on the shelf," resolved to come home. Chaytor's latest turn in South America was frustrating. "Here," he wrote from Bogota, "nothing is expeditiously done[;] 'poco a poco' is the 'sine qua non,' and he who possesses most patience generally succeeds best." He looked askance at the local naval officers. "The marine sector in this section of America," he complained, "is so clogged with ignorance \& ambition only to obtain the gold lace in the natives of the country, who are mostly coloured, that a foreigner stands but a poor chance with them." Chaytor took pride in Spanish American independence, but he was conflicted. Writing to W.G.D. Worthington, Chaytor reflected on his "more than 13 years of toil in the noble cause of South American emancipation." He wrote "service" but changed it to "toil." 35

Once a merchant captain of evident skill, Chaytor had risen to a position of esteem and authority, the equivalent of secretary of the navy in the United States. But success never lasted for Chaytor. The independence of South America had brought him no closer to the personal independence he sought. In the end, it was all "toil."

Captain Almeida continued privateering by taking a Colombian commission, but, increasingly harassed by U.S. law enforcement, he packed up his family and fled the country in May 1822, settling in St. Bartholomew's. Almeida's departure stemmed most immediately from a capture he had made in 1820 while commanding the Wilson/Bolivar when he had taken $\$ 5,000$ belonging to several American passengers. Starting over at St. Bart's, Almeida purchased a house in 1823, and then a warehouse and a new home overlooking the harbor in the following years. It was certainly needed as the last three of Almeida's ten children were born on the island. Almeida seems to have been making a decent life, but his leadership skills did not improve. There was another mutiny in 1821 , leading to a lost prize, and more men were denied their money. They filed yet another suit, but with the captain out of U.S. jurisdiction, they had little chance for recovery. Independence still eluded him $^{36}$

notice of J.A.B., 1824, JCPP; New Bedford (MA) Mercury, 19 September 1823; Baltimore Patriot, 10 February 1824.

35 Quotes: Chaytor to W.G.D. Worthington, 14 December 1826, JCPM; Chaytor to Robert K. Lowry, 20 January 1826; Chaytor to Worthington, 5 July 1825, JCPP. See also David Head, "Baltimore Seafarers, Privateering, and the South American Revolutions, 1816-1820," Maryland Historical Magazine, 105 (2008), 269-293.

36 Seims, "Joseph Almeida," 9-10; libel of Jonathan Manro, 17 May 1822, Manro v. Almeida, DCMD Adm. Baltimore Patriot, 24 May 1821, 26 December 1821, 17 March 1823, 13 August 1823; Baltimore Patriot, 24 May 1821; depositions of William Smith and Robert Nye, William Smith and Others v. The Schooner Mary, Historical Society of Pennsylvania, Edward Carey Gardiner Collection, 16 September 1823. 


\section{After the Spanish American Victory}

The last Spanish forces in South America surrendered in January 1826. It had been almost a decade since Almeida, Chaytor, and Danels had left their careers as American sea captains to sail for South America. They had sailed thousands of miles, capturing millions of dollars worth of enemy property, and faced dozens of lawsuits. Now, with independence achieved, they might have been expected to draw back from South America. Yet, they did not. For better or for worse, Spanish American privateering was the most significant experience of their lives and it continued to mark them.

Almeida, for example, found a new war. In 1825, Buenos Aires had commenced hostilities against Brazil over the Banda Oriental. Conquered by the Portuguese, the territory became part of Brazil when it achieved its independence in 1822. Three years later, rebels backed by Buenos Aires sought to break away and to join the Spanish-speaking republic across the river. Both sides employed scores of foreign soldiers and sailors, principally Britons but also Americans, Frenchmen, Spaniards, and Italians. Eventually, with the war at a standstill both sides grew impatient, and Britain, whose trade to the River Plate suffered, brokered a peace settlement. The Banda Oriental would become Uruguay, an independent nation and buffer between the antagonists. The war, of course, meant privateering. Almeida went back to work for his old employer. ${ }^{37}$

In 1827, Almeida owned a new vessel, the Pichincha, named after the battle that freed what would become Ecuador. Cruising without him off the coast of Brazil, the privateer captured the slave ship Surinam and her 230 slaves. The Surinam sailed to St. Eustatis, but since a case of smallpox had been reported aboard, the vessel went to serve its quarantine at Saba, a notorious smuggling outpost nearby. Both islands were Dutch, and although the Netherlands had outlawed the slave trade in 1814, demand for slaves continued and smugglers helped keep up supply. Almeida may have had just that in mind. Almeida was a slave owner himself - his slave York Davy had sailed aboard the Congresso and earned one-and-a-half prize shares, which Almeida claimed - and during the War of 1812, Almeida had attempted to claim slaves captured from a British vessel as prize. Buenos Aires had established a satellite prize court at St. Bart's, where Almeida still resided, but the Surinam was not ordered there. The fate of the slaves is unknown, since a mutiny occurred before any transactions could be completed, and Almeida lost control of the vessel. ${ }^{38}$

Captain Almeida made a climactic exit from the Spanish American service. Commanding the Presidentia, Almeida called at Puerto Cabello to inquire after a prize that had been detained by the Colombian government. He sent a man ashore but he, too, was

37 Brian Vale, A War Betwixt Englishmen: Brazil Against Argentina on the River Plate (New York, 2000), 16, 26-27.

38 The Baltimore Patriot, 28 January 1829, describes this incident. For the prize court at St. Bart's, see Vale, War Betwixt Englishmen, 188. An 1814 edict made slave trading illegal in Dutch colonies. An 1818 treaty with Britain committed the Netherlands to ending the international trade, though smuggling to Dutch islands persisted. See P.C. Emmer, The Dutch Slave Trade, 1500-1850 (New York, 2006) trans. Chris Emery, 114-125. 
detained. Some time before, the Colombians had declared Almeida an outlaw when he failed to return his commission as instructed, and this seemed to be the trouble now. While waiting offshore, Almeida's men - always prone to grumbling - grew impatient, rose on the officers, and imprisoned their captain. The mutineers headed for San Juan, Puerto Rico. The Spanish had issued a proclamation calling for the arrest of Almeida as a notorious pirate, and there may have been a reward for his capture. Authorities took him into custody. Thirteen years after his confinement in Cartagena, Almeida was back in a Spanish prison. This time no one would intervene. His wife, Theresa, moved with the children to Baltimore to be close to her family. Almeida lost his independence and then his life. After lingering in a San Juan cell for almost three years, he was executed for piracy in February $1832 .^{39}$

Chaytor returned to Baltimore in 1828, but he never could retire. Instead, he started a new business as a ship factor. Taking out an advertisement in the Baltimore Patriot, he offered his services as agent in any and all commercial transactions. He would see to the building, purchase, sale, or furnishing of vessels. He would find vessels ready for charter. He would broker sales of goods - whether whole ships' cargoes or a captain's private adventures. He would be a friend to travelers, offering a fount of local intelligence, and he would look after a fellow Baltimorean's business while away. Chaytor called particular attention to his vast knowledge of "Baltimore schooners" since "the last twentyfive years of the subscriber's life [have] been generally spent in command of the most splendid "clippers." Chaytor also offered to help anyone going to South America. He promised "information essential to comfort and safety-all acquired from actual observation and experience." Chaytor then embarked on a fifteen year career as a steamboat captain, transporting passengers between Baltimore and Philadelphia, first in the Carroll of Carrollton and later in the Constitution. Some adventures ensued. The newspapers note that he was blamed for a crash on one occasion and helped rescue the victims of a steamboat explosion on another. He also met the legendary frontiersmanturned-politician David Crockett passing through Baltimore. Chaytor seems to have been well-liked in his new occupation- "A good fellow he is," said Crockett—but more and more he was described as an old captain, less and less as the Spanish American commodore he had once been. Upon Chaytor's death in 1846, the obituary called him "the oldest and most experienced steamboat commander that belonged to the port of Baltimore." It made no reference to his earlier life as Diego. ${ }^{40}$

39 Baltimore Patriot, 19 February 1829; Providence (RI) Patriot and Colombian Phoenix, 16 May 1829; Seims, Joseph Almeida, 11. While in prison Almeida was visited by a young Manuel Alonso, who would become one of Puerto Rico's most celebrated writers. In El Jibaro, considered the first work of Puerto Rican literature, Alonso recorded how his father, a friend of the prison warden, took him to see the infamous pirate. See Manuel Alonso, El Jibaro (1849; rep., University of Wisconsin-Madison, 2003), http://digital.library. wisc.edu/1711.dl/IbrAmerTxt.Spa0018 (accessed September 17, 2009); Manuel Juan Canino Salgudo, "Puerto Rico: Caribbean Cultural Center," in Literary Cultures of Latin America: A Comparative History ed. Mario J. Valdes and Djebal Kadir, (2 vols., New York, 2004), 2 : 396-397.

40 Quotes: Easton (MD) Gazette, 31 January 1835; Baltimore Sun, 19 January 1846. See also 
For the other commodore, Commodore Danels, life after Spanish American independence was entirely different. Following his release from Puerto Cabello, Danels returned to Baltimore and moved his family out of their home on Alisana Street, in the Fell's Point sailor town, to a tonier neighborhood on Albermarle Street. Danels commissioned another portrait, this time of his children: John, Lewis, James, Eugenia, and Elizabeth. (Another son, Bolivar, would be born in 1826.) Included in the picture are two youths of African descent: Manuel and Thomas Páez, the sons of Colombian general and future president of Venezuela José Antonio Páez. The general had sent them north to attend St. Mary's College. Danels saw to their education alongside his son John. He paid for their board and tuition, doctor and dentist, classes in music and drawing, and, at \$17 each, dancing lessons, too. By the 1820s, St. Mary's had become the city's elite school for boys, both Catholic and Protestant. Eventually, all five Danels sons would attend, and they would learn in the same classrooms as the upper crust of Baltimore society: the Dorseys, McKims, McBlairs, Latrobes, Ridgelys, and Pattersons all sent their boys to St. Mary's. The Spanish consul, John B. Bernabeau, also sent his son there. School events would have been awkward. ${ }^{41}$

In retirement, Danels dabbled in commerce. In 1831 he launched a short-lived commission, chandlery, and grocery business. Much later, Danels became a partner in a brewery. Danels also pursued trade in South America. Once he sent a cargo of flour to Brazil. Another time he sold munitions to Colombia. In the late 1820s Danels had a dispute with a business partner that led him to seek temporary relief from creditors, but overall the Danels family lived comfortably. ${ }^{42}$

Danels took more of an interest in charity and religion as he grew older. When the Catholics of his neighborhood needed a new church, Danels lent a hand. He became vice president of the St. Vincent de Paul Benevolent Association and assisted in building a church as well as an orphanage for boys and a school for the poor. The day after St. Vincent's church opened in 1841, Danels bought his family a pew. For $\$ 400$ he got one of the nicest seats available. Danels was not Catholic himself, though his wife, Eugenia, a

Baltimore Patriot, 14 July 1829, 18 March 1830, 22 July 1830, 18 June 1831, 17 February 1834; Baltimore Gazette and Daily Advertiser, 7 August 1832, 26 January 1835; New York (NY) Spectator, 20 April 1842; National Gazette (Philadelphia), 30 May 1833. I would like to thank Kirk LeCompte for sharing his research on Chaytor.

41 Finance Records, March 1, 1826, St. Mary's Seminary and University, St. Mary's College Collection, 1 March 1826; The Baltimore Directory, Corrected up to June, 1819 (Baltimore, 1819), in "U.K. and U.S. Directories, 1680-1830," ancestry.com (accessed November 23, 2009); Matchett's Baltimore Director for 1827 (Baltimore, 1827), 71; Four Generations of Commissions: The Peale Collection of the Maryland Historical Society, comp. Eugenia Calvert Holland, Romaine Somerville, Stiles Tuttle Colwill, and K. Beverly Whiting Young (Baltimore: Maryland Historical Society, 1975), 104, 170-171; Memorial Volume of the Centenary of St. Mary's Seminary of St. Sulpice, 1791-1891 (Baltimore, 1891), 79-158.

42 Petition of William H. Gatchell, William H. Gatchell v. Henry H. Williams, Maryland State Archives, Baltimore County Court, Chancery Papers, 9 June 1829; Baltimore Patriot, 22 April, 16 May, and 20 May 1831; William J. Kelley, Brewing in Maryland: From Colonial Times to the Present (Baltimore, 1965), 86-87. 
French émigré from Haiti, and the children were. In 1851 Danels joined them, receiving the sacrament of baptism at St. Vincent's. Whatever sins he may have committed to attain it were washed away that day, but he held onto the title he earned privateering. The parish

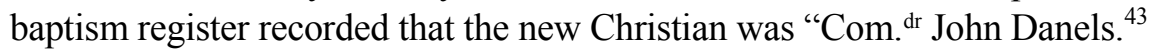

\section{Conclusion}

Two of the captains forged a new identity in South America. Chaytor became Diego. Danels became the glorious commodore, a man made wealthy, well-connected, and respectable fighting for the independence of Spanish America. Almeida's conception of his identity is less apparent, and he certainly did not choose to be branded a Spanish American pirate, but it was a far cry from his origins in the Azores or his merchant services in the United States.

Whatever the case, these identities emerged over time, and there is no evidence that any of the captains had a preexisting interest in Latin America, let alone sympathy for its independence, even when they first accepted commissions. Following each man's career shows how they made choices and how those choices changed them. Money was always important. But the cause of liberty was also present in their minds. Their independence was both the personal freedom that privateering could bring as well as the political independence of the new nations of Spanish America.

Ultimately, the biographies of Captains Chaytor, Almeida, and Danels show that a social history of captains is possible and desirable. Even though shipboard relations between captains and sailors could be fraught with tension - if not hostility - there is no reason to replicate that division in our own histories. Telling the story of sailors' notions of liberty only captures part of what was going on in the minds of the men who, after all, set sail together.

$$
* * *
$$

The author would like to thank the staffs of the Maryland History Museum, the Princeton University Rare Books and Special Collections Library, and the National Archives Mid-Atlantic branch in Philadelphia for their research assistance as well as the journal's editor and anonymous reviewers for their help preparing this article for publication.

43 Register of Baptisms, St. Vincent de Paul Roman Catholic Church, May 24, 1851; Session Laws, 1840, Archives of Maryland (899 vols., Baltimore and Annapolis, 1883-), 592: 45, http://www.msa.md.gov/megafile/msa/speccol/sc2900/sc2908/000001/000592/html/am592-45.html (accessed 9 November 2009); Thomas W. Spalding, St. Vincent de Paul of Baltimore: The Story of a People and Their Home (Baltimore, 1995), 28-33. I am grateful to Fr. Richard Lawrence for locating Danels's baptism record. 